\title{
PENGEMBANGAN TAMAN BACAAN MASYARAKAT SEBAGAI SUMBER BELAJAR
}

\author{
Bintang Petrus Sitepu \\ Email: risona_stp@yahoo.com \\ FIP Universitas Negeri Jakarta
}

\begin{abstract}
Abstrak: Dalam mewujudkan masyarakat gemar belajar melalui gemar membaca, Taman Bacaan Masyarakat (TBM) memainkan peranan yang sangat penting dan strategis karena TBM berdiri oleh, untuk, dan berada di tengah-tengah masyarakat. Oleh karena itu masyarakat dan Pemerintah Indonesia berupaya mengembangkan TBM sampai ke desa-desa. Penelitian ini bermaksud memberikan gambaran bagaimana perkembangan TBM yang diberikan bantuan dana oleh Pemerintah agar dapat berfungsi sebagai suatu pusat sumber belajar di tengah-tengah masyarakat. Penelitian yang dilakukan di 7 (tujuh )TBM yang tersebar di 4 (empat) Kabupaten di Provinsi Banten dalam bulan Juni sampai November 2011. Data dikumpulkan dengan teknik observasi, wawancara, dan studi dokumen yang kemudian diolah dan dianalisis secara kualitatif. Hasil penelitian ini menunjukkan pada umumnya perkembangan TBM yang memperoleh dana bantuan tidak seperti yang diharapkan, dilihat dari pengelolaan, jumlah koleksi, kegiatan, dan jumlah pengunjung. TBM yang bertahan dan berkembang ialah TBM yang didirikan dan dikelola oleh anggota masyarakat yang memiliki motivasi dan idealisme untuk mencerdaskan masyarakat sekitarnya. Penelitian ini memberikan sejumlah saran yang antara lain ialah perlunya meningkatkan monitoring dan pengawasan TBM yang memperoleh dana bantuan dari Pemerintah.
\end{abstract}

Kata-kata Kunci: Taman Bacaan Masyarakat, bantuan dana, sumber belajar

\section{DEVELOPING COMMUNITY READING CENTERS (CRC) AS A LEARNING RESOURCES CENTER}

\begin{abstract}
Learning society is established and developed starting from reading community within this is in the mind, the role of Community Reading Centers (CRC) holds a strategic position in developing the community to become a reading and learning society. The Indonesian community and goverment made significant efforts to diseminate CRC through out Indonesia. This research was intended to describe the development of CRC particularly of those achieved financial assistance from the government. The research was conducted at 7 (seven) CRCs spread out in Banten Province in June through November 2011. Applying qualitative paradigm, the research collected data using observation, interview, and study document techniques. The data were analyzed qualitatively to draw conclusions and suggestions. The research findings show that the development of CRCs received the grant is not as expected. Based on the findings the research suggest the concerned institutions to intensify monitoring and supervision on the CRCs.
\end{abstract}

Keywords: Community Reading Centers, financial assistance, learning resources

\section{PENDAHULUAN}

\section{Latar belakang}

Kualitas sumber daya manusia merupakan modal dasar bagi suatu negara untuk membangun masyarakat dan bangsanya yang makmur dan berkeadilan. Oleh karena itu, pembangunan pendidikan merupakan sebuah investasi masa depan dalam rangka menyiapkan manusia berkualitas yang mampu menghadapi tantangan dan persaingan global. Pembangunan pendidikan dalam rangka peningkatan sumber daya manusia yang berkualitas tidak dapat dilaku- kan secara fragmental dan terkotak-kotak, melainkan harus diselenggarakan secara terpadu dan sinergis melalui berbagai jenis, jenjang, dan jalur pendidikan. Pendidikan bukanlah kegiatan yang terkotak-kotak, dilakukan untuk waktu tertentu, dalam tempat-tempat tertentu, dan pada suatu rentang kehidupan tertentu. Pendidikan adalah sebuah proses yang berlangsung sepanjang hayat melalui jalur pendidikan formal, nonformal, dan informal.

Sejalan dengan pemikiran di atas, Direktorat 
Jenderal Pendidikan Nonformal dan Informal menetapkan visi, yaitu "Terwujudnya Manusia Indonesia Pembelajar Sepanjang Hayat". Dalam rangka mewujudkan visi tersebut maka salah satu misinya adalah mendorong terwujudnya masyarakat belajar sepanjang hayat melalui peningkatan budaya baca serta penyediaan bahan-bahan bacaan yang bermutu, berguna, dan relevan baik bagi aksarawan baru maupun anggota masyarakat lainnya agar berpengetahuan, berketrampilan, berbudaya, maju, dan mandiri melalui perluasan Taman Bacaan Masyarakat (TBM). Salah satu faktor yang mendukung upaya peningkatan budaya baca adalah terciptanya perluasan dan peningkatan mutu layanan TBM. Dengan demikian, kehadiran TBM merupakan sebuah medium yang sangat strategis bagi peningkatan budaya baca masyarakat.

TBM, yang tumbuh dari, oleh, dan untuk kepentingan masyarakat, merupakan salah satu indikasi penting dari demokratisasi di bidang pendidikan dan sekaligus merupakan perwujudan tanggung jawab masyarakat terhadap layanan pendidikan. Namun, kondisi TBM yang ada selama ini masih menghadapi berbagai kendala untuk menjadi sebuah sumber belajar sepanjang hayat bagi seluruh lapisan masyarakat. Kondisi sarana/prasarana, jumlah dan jenis bahan bacaan, profesionalisme pengelolaan, mutu layanan, dan jaringan kerja kemitraan dari TBM selama ini masih perlu diperbaiki dan ditingkatkan, jika TBM benarbenar diharapkan menjadi sebuah pusat pembelajaran yang bermutu.

Untuk lebih memberdayakan TBM, sejak tahun 2003 Pemerintah melalui Direktorat Jenderal Pendidikan Luar Sekolah menyalurkan bantuan dana ke TBM secara bertahap. Mulai tahun 2005 bantuan itu disalurkan dalam bentuk block grant oleh Direktorat Jenderal Pendidikan Luar Sekolah (yang mulai tahun 2007 disebut Direktorat Jenderal Pendidikan Nonformal dan Informal). Alokasi dana yang disalurkan bertambah setiap tahun dan telah mencapai Rp. 261.926.000.000,00 sejak tahun 2005 sampai tahun 2011.

Penting dan strategisnya kedudukan TBM dalam membangun masyarakat membaca serta besarnya dana yang telah diberikan Pemerintah mengembangkan TBM, perlu diteliti sejauh mana TBM tersebut telah berkembang dan berfungsi seperti yang dikehehendaki.

Berdasarkan latar belakang yang telah dikemukakan maka masalah yang diteliti dalam penelitian ini ialah: "Bagaimana pengaruh pemberdayaan TBM melalui dana bantuan dari Direktorat Pendidikan Masyarakat Ditjen PNFI terhadap perkembangan TBM yang menerima bantuan itu?"
Agar masalah penelitian lebih terfokus, maka keadaan TBM sebelum dan sesudah menerima TBM diteliti dari segi (1) kelembagaan (struktur organisasi TBM), (2) jumlah dan kemampuan pengelola, (3) koleksi, (4) sarana pendukung, (5) kegiatan, (6) jumlah pengunjung, (7) jumlah peminjam, (8) jumlah bahan bacaan yang dipinjam, serta (9) kesan-kesan pengunjung TBM. Aspek-aspek ini diteliti dengan pertimbangan secara keseluruhan sehingga aspek-aspek tersebut dapat dijadikan indikator perkembangan TBM sebelum dan sesudah menerima bantuan.

Pemerintah memberikan dana bantuan pemberdayaan TBM kepada TBM yang memenuhi syarat di seluruh Indonesia. Akan tetapi penelitian ini membatasi lingkup geografis penelitian di Provinsi Banten. Provinsi ini dipilih sebagai kasus, mengingat keadaan sosial dan ekonomi masyarakat di Provinsi ini cukup bervariasi dan sebagian daerah ini berbatasan dengan dan dekat ke DKI Jakarta sebagai Ibu Kota Republik Indonesia yang memiliki berbagai sumber belajar. Sebagian lagi berbatasan dengan Provinsi Jawa Barat serta jauh dari berbagai sumber belajar.

Penelitan ini bermaksud untuk mengetahui dan mendeskripsikan perkembangan TBM yang telah dibantu dengan dana oleh Direktorat Pendidikan Masyarakat Ditjen PNFI, Kementerian Pendidikan Nasional tahun 2009. Hasil penelitian ini diharapkan bermanfaat untuk (1) menjadi salah satu rujukan dalam melakukan penelitian sejenis lebih lanjut, (2) merumuskan kebijakan lebih lanjut dalam mengembangkan TBM dengan bantuan dana dari Pemerintah, (3) memberikan alternatif pemecahan masalah dalam mengembangkan TBM, dan (4) meningkatkan efektifitas dan efisiensi pemberian dana bantuan Pemerintah ke TBM.

\section{Kajian Teoretis}

Ditelusuri dari pertumbuhan dan perkembangannya, TBM bukan merupakan sesuatu yang baru tetapi sudah ada sejak lama ketika masyarakat mulai mendirikan tempat membaca dan menyewakan buku yang pada umumnya adalah buku cerita dalam bentuk novel atau komik. Tempat yang demikian berada di tengah-tengah pemukiman masyarakat, diselenggarakan oleh dan untuk masyarakat. Melihat pentingnya mencerdasakan masyarakat dengan membaca, pada awal tahun 1950-an Pemerintah mendirikan Pustaka Rakyat yang kemudian berkembang menjadi Taman Bacaan Masyarakat. Akan tetapi, sangat sedikit sekali ditemukan referensi untuk dapat mengetahui teori yang mendasari tumbuh dan berkembangnya TBM ini. Peneliti-peneliti TBM pada umumnya menggunakan kebijakan-kebijakan Pemerintah dalam bentuk 
Undang-Undang, Keputusan Presiden, Keputusan Menteri, Keputusan Dirjen, Pedoman atau Panduan yang dibuat pada tingkat Direktorat, tulisan-tulisan di surat kabar dan internet sebagai referensi.

Pada awalnya, TBM tumbuh dan berkembang secara alamiah dalam arti dibentuk atas inisiatif atau prakarsa anggota masyarakat sendiri, tanpa landasan teori atau pedoman yang baku. TBM bertujuan untuk menyediakan bahan bacaan untuk masyarakat sekitarnya. Memperhatikan proses pembentukan, pengelolaan, dan pemanfaatan TBM yang demikian maka penelitian ini pun tidak menggunakan landasan teoretis formal yang berfungsi untuk menjelaskan, memecahkan masalah, dan melakukan prediksi atas fenomena TBM. Pendekatan yang dipakai dalam penelitian adalah paradigma penelitian kualitatif naturalistik khususnya jenis fenomenologi.

Keberadaan, pemanfaatan, serta perkembangan TBM tidak dapat dipisahkan dengan kemampuan dan minat baca masyarakat yang ada di sekitarnya. Sungguhpun bangsa Indonesia masih memiliki angka buta huruf sekitar $10 \%$ dari penduduk usia 15 tahun ke atas dan jauh lebih tinggi lagi ketika masa penjajahan Belanda dan Jepang, minat baca msyarakat telah tumbuh. Walaupun dalam masa penjajahan, kesempatan memperoleh pendidikan tidak terbuka untuk seluruh kalangan masyarakat, minat membaca itu sudah ada di kalangan masyarakat tertentu. Sejarah perjuangan tokoh bangsa Indonesia menunjukkan bahwa di tempat-tempat tahanan pun mereka menggunakan waktunya untuk membaca. Sebagai contoh, rumah tawanan Soekarno di Ende, Flores, dan Bengkulu dan juga tempat-tempat lainnya masih menyimpan puluhan judul buku bacaan mereka.

Minat dan kegemaran membaca di kalangan masyarakat biasa terlihat dari munculnya tempat baca dan penyewaan buku yang pada awalnya banyak dikelola oleh etnis Tionghoa dengan bahan bacaan dalam aksara Tionghoa, Melayu, dan Indonesia. Tempat-tempat itu ramai dikunjungi berbagai lapisan masyarakat dan tingkat usia. Kebanyakan isi bahan bacaan berkaitan dengan cerita silat, petualangan, novel, dongeng, dan lelucon serta terdapat juga bukubuku ilmu pengetahuan dan keterampilan walaupun jumlahnya tidak sebanyak buku cerita fiksi lainnya.

Di pihak lain, masing-masing agama di Indonesia memiliki kitab suci yang untuk memahami dan melaksanakan isinya perlu dibaca oleh umatnya. Di dalam agama Islam, misalnya sejak kecil anak sudah diajari mengaji dan membaca Al-Qur'an. Hal yang sejenis juga terjadi di agama lain. Kitab suci dijadikan bahan bacaan dan rujukan diskusi untuk memperdalam dan memperkuat imannya. Dengan demikian, kegiatan membaca itu bukan hal yang asing bagi masyarakat Indonesia, akan tetapi jenis aksara dan isi bahan bacaannya berbeda.

\section{Taman Bacaan Masyarakat (TBM)}

Upaya menumbuhkan dan mengembangkan minat dan kegemaran membaca terus dilanjutkan oleh Pemerintah dengan memberikan bantuan kepada Taman Bacaan. Pada tahun 1992, Departemen Pendidikan dan Kebudayaan, yang sekarang ini disebut Kementerian Pendidikan dan Kebudayaan, melalui Direktorat Pendidikan Masyarakat, memberikan bantuan dengan tujuan utama mempertahankan dan mengembangkan kemampuan membaca masyarakat yang sudah bebas dari buta aksara melalui Taman Bacaan Masyarakat (TBM). Sejak dilaksanakannya program ini penggunaan nama TBM semakin dikenal, walaupun masih ada juga yang menggunakan nama TB, khususnya yang tidak mengikuti program ini (Direktorat Pendidikan Masyarakat, 2009).

Dalam hubungannya dengan pemberian bantuan kepada TBM, pengertian/ definisi TBM semakin diperjelas. TBM diartikan sebagai sebuah tempat/ wadah yang didirikan dan dikelola baik oleh masyarakat maupun Pemerintah, yang berfungsi sebagai sumber belajar untuk memberikan akses layanan bahan bacaan yang sesuai dan berguna bagi masyarakat sekitar TBM, serta mengadakan berbagai kegiatan untuk mendorong tumbuhnya minat baca dalam rangka peningkatan wawasan, pengetahuan, dan keterampilan sebagai upaya mencerdaskan kehidupan bangsa. Dalam pengertian ini, TBM difungsikan sebagai sebuah sumber belajar yang mengandung makna yang luas dalam konteks kegiatan belajar. TBM tidak hanya menyediakan bahan bacaan, tetapi juga membantu menumbuhkan minat dan kegemaraan membaca masyarakat. Dengan kata lain, TBM diharapkan ikut berperan serta dalam membentuk masyarakat belajar sepanjang hayat sehingga wawasan, pengetahuan, dan keterampilan mereka terus berkembang selaras dengan perkembangan peradaban manusia.

Bantuan Pemerintah ternyata mampu menumbuhkembangkan TBM sehingga jumlahnya pun meningkat. Dari sekitar 190 TBM di Indonesia pada tahun 1992, meningkat menjadi sekitar 7.000 pada tahun 2007. Akan tetapi, karena krisis keuangan yang dihadapi Pemerintah Indonesia tahun 1987, berbagai jenis bantuan termasuk untuk TBM menjadi berkurang sehingga cukup banyak TBM yang tutup. Perlu segera dicatat bahwa sangat sulit menjamin keakuratan jumlah TBM yang sesungguhnya, karena berbeda sumber berbeda angka yang diberikan. 
Pemberian bantuan Pemerintah kepada TBM mempengaruhi pengelolaan TBM, karena Pemerintah memberikan berbagai persyaratan administrasi dan fisik yang harus dipenuhi oleh TBM yang akan menerima bantuan. Kalau sebelumnya TPB dan TB tidak dilengkapi dengan struktur organisasi yang baku serta dikelola dengan sistem administrasi yang sangat sederhana, untuk TBM yang akan menerima bantuan dari Pemerintah harus memiliki akta pendirian, struktur organisasi, administrasi, dan fisik yang jelas.

Bantuan yang diberikan oleh Pemerintah kepada TBM juga dimaksudkan sebagai stimulan kepada TBM untuk mengembangkan kegiatannya tidak hanya sebagai tempat membaca, tetapi juga menjadikan TBM sebagai pusat sumber belajar masyarakat. Di berbagai TBM diselenggarakan lomba membaca, membuat sinopsis, dan ada juga yang menyelenggarakan kursus Paket A (Direktorat Pendidikan Masyarakat, 2005).

Kehadiran TBM yang dibantu oleh Pemerintah tidak menghentikan upaya masyarakat yang tetap melakukan usaha TPB dan TB. Masih banyak terdapat TPB dan TB di kota-kota besar yang tetap melakukan kegiatannya secara tradisional serta masih tetap diminati masyarakat sekitarnya.

Untuk memberikan pelayanan pendidikan dan pelatihan kepada masyarakat, Pemerintah mendirikan dan mengembangkan Pusat Kegiatan Belajar Masyarakat (PKBM) yang dibina melalui jalur pendidikan nonformal. PKBM ini dikembangkan sampai tingkat kecamatan dengan kegiatan menyelenggarakan kursus Paket A, B, dan C serta berbagai pelatihan keterampilan. Sebagai salah satu sumber belajar, PKBM memiliki TBM dengan koleksi bahan bacaan yang pada umumnya buku-buku paket kursus dan pelatihan serta sejumlah buku umum. Dengan demikian, maka TBM PKBM ini merupakan milik, dikelola, dan didanai oleh Pemerintah.

Model PKBM yang dikembangkan Pemerintah ini juga kemudian diterapkan oleh masyarakat dengan dana sendiri dan/ atau dana bantuan dari Pemerintah. Struktur organisasi dan jenis kegiatan yang dilakukan disesuaikan dengan kebutuhan masyarakat setempat dan kemampuan masing-masing PKBM. Sejumlah TBM berkembang menjadi PKBM yang dikelola oleh masyarakat.

\section{Jenis-Jenis TBM}

Dalam memberikan bantuan kepada TBM, Pemerintah membedakan TBM berdasarkan perkembangan TBM dengan kategori: (1) TBM rintisan penguatan keaksaraan, (2) TBM penguatan minat baca, (3) TBM komunitas khusus, dan (4) TBM@mall (Direktorat Pendidikan Masyarakat,2009 \& Ella, 2010).

\section{TBM Penguatan Keaksaraan (TBM PK)}

TBM PK bertujuan terutama untuk meningkatkan kemampuan membaca masyarakat untuk memperoleh, memilah, dan menggunakan informasi sesuai dengan keperluannya. Dengan tujuan yang demikian maka sasaran pelayanan TBM PK diarahkan kepada mereka yang masih memiliki kemampuan membaca awal seperti aksarawan baru, melek aksara parsial, dan anak usia dini. Tujuan dan sasaran tersebut melandasi penyediaan bahan bacaan dan pelaksanaan kegiatan di TBM PK.

Bahan bacaan di TBM PK merupakan bukubuku dan majalah-majalah yang sederhana dan mudah serta menarik dibaca, berisi informasi, pengetahuan, dan keterampilan praktis. Sedangkan, kegiatan yang dilakukan mencakup diskusi-diskusi kecil untuk meningkatkan kemampuan membaca serta meningkatkan pengetahuan umum masyarakat.

\section{TBM Penguatan Minat Baca (TBM PMB)}

TBM PMB bertujuan terutama untuk meningkatkan dan menguatkan minat baca warga masyarakat sehingga menjadi kebiasaan dan kegiatan rutinitas sehari-hari masyarakat. Tahap penguatan minat baca ini diharapkan dapat menjadi dasar kuat bagi warga masyarakat untuk belajar sepanjang hayat. Mengacu pada tujuan TBM PMB, koleksi bahan bacaan yang disediakan diarahkan pada bahan-bahan yang memotivasi warga masyarakat untuk membaca dan belajar secara terus menerus sepanjang hayat.

Agar kemampuan membaca, menulis, dan berhitung mereka berkembang, maka TBM PMB menyediakan bahan bacaan yang isinya sesuai dengan kebutuhan mereka. Seperti tentang kesehatan, keterampilan praktis yang dapat meningkatkan efektivitas dan efisiensi kerja dalam bertani, beternak, atau kerajinan tangan. Untuk masyarakat yang lebih maju, TBM PMB menyediakan informasi praktis, buku-buku peningkatan pengetahuan terapan tentang sains dan teknologi, kewirausahaan, pendidikan kebangsaan, moral dan budi pekerti, sejarah dan autobiografi, dan minimal 5 judul buku karya sastra serta bahan multimedia elektronik.

\section{TBM Komunitas Khusus (TBM KK)}

TBM KK memberikan pelayanan kepada kelompok masyarakat yang memiliki karakteristik khusus, sehingga bahan bacaan dan tata cara pelayanannya pun disesuaikan dengan ciri kelompok tersebut. Kekhususan TBM KK didasarkan pada demografi dan geografi tertentu yang bersifat khas dan berbeda dengan komunitas lainnya, dengan tujuan menggali dan mengembangkan kompetensi komunitas yang menjadi sasaran pelayanan TBM KK. Contoh kelompok 
masyarakat berkarakteristik khsusus ialah penghuni lembaga pemasyarakatan, penghuni rumah jompo, penduduk desa nelayan, penduduk di daerah khusus pertanian, dan penduduk di daerah pariwisata, di daerah perbatasan, dan desa yang tertinggal.

Komunitas khusus tersebut biasanya mengalami kesulitan dalam memperoleh informasi, sehingga mereka tidak dapat mengikuti perkembangan ilmu pengetahuan dan teknologi, dan memiliki cara dan sikap berpikir, serta berperilaku tradisonal dan tertinggal dari masyarakat lain.

4. TBM@Mall

Dewasa ini berkembang berbagai jenis pusat perbelanjaan khusunya di kota-kota besar di Indonesia. Kenyamanan berbelanja dan penataan lingkungan yang menarik membuat pusat-pusat perbelanjaan ini ramai dikunjungi oleh berbagai kalangan, khususnya golongan masyarakat mengah ke atas. Salah satu jenis pusat perbelanjaan itu ialah Mall, yang pada waktu-waktu tertentu menyelenggarakan berbagai atraksi untuk menarik dan menghibur pengunjung. Mall kemudian tidak hanya berfungsi sebagai tempat belanja, tetapi juga menjadi tempat rekreasi yang ramai dengan pengunjung.

Sasaran membentuk masyarakat belajar melalui gemar membaca adalah semua lapisan masyarakat. Salah satu pendekatan yang dilakukan Pemerintah melalui program Pendidikan Masyarakat ialah proaktif mendekatkan bahan bacaan dan menumbuhkembangkan gemar membaca di tengah-tengah masyarakat. Salah satu cara yang dilakukan oleh Kementerian Pendidikan Nasional ialah mendirikan TBM di Mall dengan bekerja sama dengan pengelola Mall. TBM di Mall itu diberi nama TBM@Mall. Penggagas, pendiri, dan pengelola TBM@Mall adalah anggota masyarakat, sedangkan pengelola memberikan kemudahan dalam penyediaan tempat.

Tujuan TBM@Mall ialah menumbuhkembangkan minat baca pengunjung mall dengan menyediakan berbagai jenis bahan bacaan serta kegiatan yang relevan. Oleh karena karakteristik pengunjung Mall sangat bervariasi, jenis bahan bacaan dan kegiatan promosi peningkatan minat dan gemar membaca juga beraneka ragam. Bahan bacaan yang disediakan diharapkan dapat menarik dan memotivasi pengunjung untuk membaca, seperti novel, pengetahuan populer, keterampilan praktis, dan berbagai informasi yang dibutuhkan oleh pengunjung. Pada waktu-waktu tertentu dilakukan diskusi tentang isi buku tertentu, temu pengarang, pemutaran film dokumenter, pelatihan karakter, dan berbagai permainan dan lomba yang berkaitan dengan membaca dan belajar.

\section{Bantuan Pemerintah Untuk Pengembangan TBM}

Pemerintah mengamati bahwa TPB, TB, dan TBM berada benar-benar di tengah masyarakat, dan pada awalnya didirikan, dikelola, dan dikembangkan oleh masyarakat secara mandiri. TPB, TB, dan TBM merupakan wadah yang strategis dalam menumbuhkembangkan kemampuan, minat, dan kegemaran membaca masyarakat menuju masyarakat gemar membaca dan gemar belajar. Oleh karena itu, Pemerintah melalui Direktorat Pendidikan Masyarakat melakukan berbagai upaya yang antara lain melalui kegiatan pendirian TBM serta pemberian subsidi bagi lembaga penyelenggaraan TBM. Pemberian subsidi ini diharapkan dapat meningkatkan pelayanan TBM sejalan dengan meningkatnya kualitas dan kuantitas bahan bacaan sesuai dengan kebutuhan masyarakat. Di samping itu, dilakukan pula pelatihan pengelolaan TBM, pelaksanaan workshop TBM, dan pembentukan forum komunikasi dan pengelola TBM yang melibatkan berbagai unsur masyarakat yang peduli pada minat baca. Kegiatan tersebut didukung dengan penyusunan berbagai pedoman, seperti pedoman pengelolaan TBM dan pedoman pelatihan pengelola TBM yang diikuti dengan sosialisasi berbagai pedoman itu.(www.bappenas.go.id/get-file-server/node/6180/hlm 22)

Dari berbagai jenis bantuan yang diberikan Pemerintah, penelitian ini membatasi pada bantuan dana yang diberikan oleh Pemerintah melalui Direktorat Pendidikan Masyarakat dalam tahun 2010 yang hasilnya seharusnya sudah terlihat dalam tahun 2011

1. Dana bantuan

Direktorat Pendidikan Masyarakat memberikan kategorisasi bantuan berdasarkan tingkat perkembangan TBM. Lihat tabel 1.

Tabel 1. Kategorisasi TBM dan Jumlah Dana Sosial yang Diberikan

\begin{tabular}{|c|l|c|}
\hline No & \multicolumn{1}{|c|}{ Kategori TBM } & Jumlah Dana \\
\hline 1 & Rintisan & Rp. 10.000 .000 \\
\hline 2 & Penguatan Minat Baca & Rp. 15.000 .000 \\
\hline 3 & TBM KK & Rp. 70.000.000 \\
\hline 4 & TBM@Mall & Rp. 70.000.000 \\
\hline
\end{tabular}

Dilihat dari kategori TBM seperti tertera dalam tabel di atas, maka TBM yang diteliti termasuk TBM Rintisan atau disebut juga TBM Penguatan Keaksaraan. TBM Penguatan Keaksaraan merupakan TBM yang meyediakan bahan bacaan untuk memberikan layanan kepada anak usia dini, melek aksara parsial, aksarwan baru, peserta didik pendidikan dasar, anak yatim di panti asuhan, dan masyarakat pada umum- 
nya yang bertujuan untuk meningkatkan kemampuan keberaksaraan

Pemberian dana program TBM Penguatan Keaksaraan dimaksudkan untuk menyediakan, memperluas, dan memeratakan akses TBM sehingga menjangkau dan memberikan layanan peningkatan keberaksaraan dan memberdayakan masyarakat (Departemen Pendidikan Nasional. 2004, 2005, 2006, 2007, 2008, \& 2009).

\section{Prosedur memperoleh dana bantuan sosial}

Prosedur memperoleh dana bantuan sosial diatur dalam pedoman yang ditetapkan oleh Direktorat Pendidikan Masyarakat sebagai berikut (Direktorat Pendidikan Masyarakat, 2009). Untuk mendapatkan dana bantuan pengembangan TBM Penguatan Keaksaraan harus memiliki (1) surat keterangan domisili lembaga, (2) surat keterangan pendirian lembaga, (3) surat rekomendasi Dinas Pendidikan Kabupaten/ Kota setempat, (4) rekening bank atas nama lembaga yang masih aktif, (5) kartu tanda penduduk yang masih berlaku, (6) NPWP, (7) izin operasional penyelenggaraan TBM dari Dinas Pendidikan Kabupaten/Kota setempat, dan (8) memiliki perjanjian sewa kontrak minimal 3 tahun ke depan bagi TBM yang menyewa prasarana tempat.

Secara teknis, TBM (1) diselenggarakan di lokasi/ tempat strategis dan mudah dijangkau oleh masyarakat, (2) memiliki ruang tersendiri setidaktidaknya $20 \mathrm{~m}^{2}$, (3) memiliki rak atau lemari buku untuk menyimpan/ menempatkan bahan bacaan, (4) memiliki pengelola TBM yang responsif gender dan berkomitmen untuk mengembangkan minat baca masyarakat, (5) memiliki bahan bacaan awal paling sedikit 20 judul, tidak termasuk buku pelajaran sekolah, dan bahan ajar pendidikan nonformal, dan (6) diutamakan pengelola memiliki usaha ekonomi di tempat TBM.

Mekanisme pengajuan dana bantuan untuk
TBM Penguatan Keaksaraan dilakukan melalui mekanisme sebagai berikut:

1. TBM Penguatan Keaksaraan mengajukan permohonan kepada direktur pendidikan masyarakat dengan melampirkan proposal.

2. Proposal dinilai melalui seleksi administrasi dan isi proposal oleh tim penilai.

3. Proposal yang memenuhi persyaratan administrasi dan isi diverifikasi ke lokasi TBM yang bersangkutan.

4. Atas dasar hasil penilaian proposal dan verifikasi lapangan Direktur Pendidikan Masyarakat memutuskan TBM yang berhak menerima dana bantuan.

5. Direktur Pendidikan Masyarakat dan TBM yang menerima bantuan membuat perjanjian kerja sama.

6. Direktur Pendidikan Masyarakat melakukan transfer dana melalui bank ke rekening TBM yang menerima bantuan.

7. Dana bantuan dipergunakan untuk (1) pembelian buku, (2) kegiatan TBM untuk meningkatkan minat dan kegemaran membaca masyarakat, dan (3) biaya operasional.

Dalam ketentuan pemberian dana kepada TBM disebutkan bahwa TBM wajib menggunakan dana tersebut sesuai dengan proposal yang diajukan oleh TBM yang bersangkutan. Untuk mengetahui pelaksanaan program TBM penguatan keaksaraan Direktorat Pendidikan Masyarakat, Dinas Pendidikan Provinsi, atau Dinas Pendidikan Kabupaten/Kota melakukan pemantauan yang antara lain dalam kunjungan lapangan, meminta laporan, atau bersumber dari informasi lain. Apabila terdapat TBM yang tidak menggunakan dana sesuai ketentuan, Direktorat Pendidikan Masyarakat memberikan sanksi wajib mengembalikan dana program ke kas Negara (Direktorat Pendidikan Masyarakat, 2009).

\section{METODOLOGI PENELITIAN}

Secara umum, penelitian ini bertujuan mendeskripsikan keadaan TBM yang telah menerima bantuan pengembangan TBM dari Pemerintah melalui Direktorat Pendidikan Masyarakat, Kementerian Pendidikan Nasional. Secara khusus, penelitian ini bertujuan untuk memberikan gambaran tentang keadaan TBM sebelum dan sesudah menerima bantuan dilihat dari (1) jenis dan jumlah koleksi, (2) jenis dan jumlah kegiatan, (3) jumlah pengunjung, dan (4) jumlah bahan bacaan yang dipinjam oleh pengunjung.

Dilihat dari tujuannya, penelitian ini termasuk penelitian deskriptif yaitu mendeskripsikan secara kuantitatif dan kualitatif fenomena TBM dari aspekaspek yang menjadi fokus penelitian. Untuk memperoleh data dan informasi yang diperlukan, penelitian ini menggunakan metode eksploratif di tempat-tempat penelitian, sehingga kalau dilihat dari tempatnya, penelitian ini termasuk penelitian lapangan yang didasarkan paradigma kualitatif yang berarti hasil penelitian ini hanya berlaku untuk objek-objek yang diteliti dan tidak untuk digeneralisasi.

Penelitian ini dilakukan di Provinsi Banten de-ngan pertimbangan Provinsi ini berbatasan dengan DKI Jakarta, Ibu Kota Republik Indonesia, yang 
merupakan kota metropolitan dan memiliki fasilitas sarana komunikasi dan informasi yang maju dan dalam kehidupan sosial sehari-hari bercampur dengan penduduk DKI Jakarta, seperti di Kabupaten dan Kota Tangerang. Tetapi Provinsi Banten juga memiliki wilayah yang masih tertinggal dalam pemanfaatan sarana komunikasi dan informasi, seperti di Kabupaten Lebak. Tingkat sosial dan ekonomi masyarakatnya juga termasuk heterogen. Di ibu kota Provinsi Banten (Serang), terdapat TBM Rumah Dunia yang dikenal secara nasional karena keberhasilannya mengelola berbagai kegiatan TBM secara swadaya dan sejak tahun 2010, pendiri TBM ini terpilih menjadi Ketua Forum TBM Tingkat Nasional.

TBM yang dipilih menjadi tempat penelitian ialah TBM yang (1) menerima dana bantuan dari Direktorat Pendidikan Masyarakat, Kemdiknas pada tahun 2010; (2) mencakup bantuan dana untuk rintisan atau penguatan; (3) berlokasi di dekat DKI Jakarta; dan (4) dapat dijangkau oleh peneliti dari segi transportasi, waktu, dan biaya.

Dengan menggunakan kriteria tesebut, dari Daftar TBM yang menerima dana bantuan yang bersumber dari Direktorat Pendidikan Masyarakat diperoleh

Tabel 2. TBM yang Diteliti

\begin{tabular}{|c|c|c|c|c|c|c|}
\hline \multirow[t]{2}{*}{ No } & \multirow{2}{*}{$\begin{array}{c}\text { Kabupaten/ } \\
\text { Kota }\end{array}$} & \multirow[t]{2}{*}{ Kecamatan } & \multirow[t]{2}{*}{ TBM } & \multirow[t]{2}{*}{ Alamat } & \multicolumn{2}{|c|}{ Bantuan Dansos } \\
\hline & & & & & Thn & $\mathrm{Rp}$ \\
\hline 1 & $\begin{array}{l}\text { Kabupaten } \\
\text { Lebak }\end{array}$ & $\begin{array}{l}\text { Kecamatan } \\
\text { Lebak Ge- } \\
\text { dong }\end{array}$ & $\begin{array}{l}\text { PKBM Rido } \\
\text { Manah }\end{array}$ & $\begin{array}{l}\text { Jl. Raya Cipanas Warung Banten, } \\
\text { Kp. Gunung Julang Desa Lebak } \\
\text { Situ Rt 05/02. Telp } 085710231088\end{array}$ & 2010 & $15,000,000.00$ \\
\hline 2 & & & $\begin{array}{l}\text { PKBM Bina } \\
\text { Hikmah }\end{array}$ & $\begin{array}{l}\text { Jl. Raya Rangkas Pandeglang } \\
\text { Km. 09, Ds. Selaraja. Hp. } \\
081318480004\end{array}$ & 2010 & $15,000,000.00$ \\
\hline 3 & & $\begin{array}{l}\text { Kecamatan } \\
\text { Rangkasbi- } \\
\text { tung }\end{array}$ & $\begin{array}{l}\text { TBM Al-Mukhli- } \\
\sin \end{array}$ & $\begin{array}{l}\text { Jl. TB. Hasan Kp. Ciseke Rt/Rw } \\
\text { 03/03 Ds. Jatimulya } 42315 \text { (0252- } \\
\text { 209852/08121859411) }\end{array}$ & 2010 & $15,000,000.00$ \\
\hline 4 & $\begin{array}{l}\text { Kabupaten } \\
\text { Tangerang }\end{array}$ & $\begin{array}{l}\text { Kecamatan } \\
\text { Ciputat }\end{array}$ & $\begin{array}{l}\text { Lembaga } \\
\text { Pelestarian } \\
\text { Pengemban- } \\
\text { gan Dongeng }\end{array}$ & $\begin{array}{l}\text { Jl. Akasia no.1 Komp.PLN RT/RW } \\
\text { 05/04, Kel.Rengar }\end{array}$ & 2010 & $15,000,000.00$ \\
\hline 5 & & $\begin{array}{l}\text { Kecamatan } \\
\text { Pasar Kemis }\end{array}$ & $\begin{array}{l}\text { Yayasan Paja } \\
\text { Mandiri }\end{array}$ & $\begin{array}{l}\text { Taman Kutabumi A 15/27, Kutabu- } \\
\text { mi, Pasar Kemis }\end{array}$ & 2010 & $15,000,000.00$ \\
\hline 6 & $\begin{array}{l}\text { Kabupaten } \\
\text { Serang }\end{array}$ & $\begin{array}{l}\text { Kecamatan } \\
\text { Serang }\end{array}$ & $\begin{array}{l}\text { Yayasan Al- } \\
\text { Ikhlas }\end{array}$ & $\begin{array}{l}\text { Komp. Ciceri Permai III Jl. Nusan- } \\
\text { tara IV Blok D.14 Rt/rw 03/19, kel. } \\
\text { Cipare (085222925552) }\end{array}$ & 2010 & $15,000,000.00$ \\
\hline 7 & Kota Serang & $\begin{array}{l}\text { Kecamatan } \\
\text { Curug }\end{array}$ & PKBM Hidayah & $\begin{array}{l}\text { JI. Raya Serang Petir KM 10, Ds. } \\
\text { Sukalaksana (081905604611) }\end{array}$ & 2010 & $15,000,000.00$ \\
\hline
\end{tabular}

Dalam penelitian yang berparadigma kualitatif, objek yang diteliti bukan merupakan sampel dari populasi, tetapi merupakan fenomena-fenomena yang berdiri sendiri. Penelitian ini dilakukan mulai bulan Juni sampai dengan bulan November 2011 dengan kegiatan studi dokumen, penyusunan instrumen, pengumpulan, pengolahan, analisis data, dan informasi, serta penulisan laporannya.

\section{Pengumpulan Data dan Instrumen Penelitian.}

Mengacu pada studi dokumen, penelitian ini menyusun fokus-fokus penelitian yaitu keadaan TBM sebelum dan sesudah menerima dana bantuan sosial dari unsur (1) jenis dan jumlah koleksi, (2) jenis dan jumlah kegiatan, (3) jumlah pengunjung, dan (4) jumlah bahan bacaan yang dipinjam oleh pengunjung. Dalam pelaksanaan penelitian unsur-unsur yang diamati berkembang pada ketenagaan dalam mengelola TBM.

Dengan berpedoman pada prinsip-prinsip penelitian kualitatif, data yang dikumpulkan menggunakan pedoman wawancara, pengamatan, dan kuesioner, serta di lapangan berkembang mengikuti keadaan TBM yang diteliti. Oleh karena itu, kekayaan data dan informasi yang dikumpulkan antar TBM dapat berbeda, walaupun tetap mengacu pada fokus dan unsur-unsur penelitian.

Agar memperoleh data dan informasi yang alamiah, terpercaya, dan akurat, penelitian ini tidak melakukan intervensi terhadap latar penelitian dan 
tidak memberitahu waktu kunjungan kepada pengelola TBM. Walaupun, terdapat juga TBM yang sudah mengetahui jadwal kedatangan peneliti sehingga diragukan keabsahan data dan informasi yang diperoleh. Akan tetapi, data dan informasi yang demikian tetap ditampilkan dan dianalisis dalam penelitian ini.

\section{Pengolahan data dan informasi}

Peneliti segera mengolah data dan informasi untuk mendeskripsikan latar masing-masing TBM dan fokus penelitian. Setelah kasus per kasus (kasus yang dimaksud adalah setiap TBM yang diteliti) dideskripsikan dan dianalisis, penelitian ini menarik kesimpulan untuk menjawab pertanyaan penelitian.

Trianggulasi

Untuk menguji keabsahan data dan informasi serta keakuratan deskripsi dan analisis, penelitian ini melakukan trianggulasi dengan menggunakan dokumen termasuk hasil-hasil penelitian yang relevan.

\section{HASIL DAN PEMBAHASAN}

\section{Deskripsi Data}

Seperti yang dikemukakan dalam Bab III, data dan informasi dikumpulkan dengan melakukan observasi/pengamatan langsung atas TBM, mengadakan wawancara dengan pengelola, serta dengan mengisi angket.

Berikut ini dideskripsikan data dan informasi tentang masing-masing TBM dengan memfokuskan pada gambar fisik bangunan dan koleksi bahan bacaan serta tentang kegiatan TBM dikaitkan dengan penggunaan dana bantuan Kemdiknas melalui Direktorat Pendidikan Masyarakat, yang diterima oleh masingmasing TBM dalam tahun 2009 atau 2010.

\section{TBM Rido Manah}

TBM RM merupakan salah satu unit dari PKBM RM yang didirikan oleh Pemerintah Kecamatan setempat yang berarti bukan dari masyarakat setempat. Sungguhpun TBM RM dikelola oleh orang yang berlatarbelakangkan pendidikan dan kepala sekolah serta juga pernah mengikuti pelatihan pengelolaan TBM, TBM RM kurang dimanfaatkan masyarakat sekitar. Pengelolaan TBM RM juga kurang didukung dengan administrasi yang lengkap dan tertib. Penggunaan dana bantuan dari Kemdiknas tidak begitu jelas karena tidak didukung oleh bukti-bukti yang terdokumenasi dengan baik. Kalaupun dana bantuan yang diterima tahun 2010 itu dipergunakan untuk mengembangkan TBM RM, penambahan bahan bacaan dan kegiatan peningkatan minat baca masyarakat tidak berlanjut.

\section{TBM Bina Hikmah}

TBM BH didirikan atas inisiatif warga masyarakat untuk memberikan kesempatan warga masyarakat belajar melalui membaca bahan bacaan yang disediakan. Oleh karena minat masyarakat memanfaatkannya, pengelola TBM BH mendirikan PKBM $\mathrm{BH}$ dengan menambah kegiatan melalui unit PAUD. Dana bantuan dari Kemdiknas dipergunakan untuk menambah koleksi TBM W dan honorarium pengelola. Akan tetapi rincian penggunaan dana tersebut tidak dapat diperoleh dalam bentuk dokumen.Sungguhpun masih melakukan kegiatan pelayanan bahan bacaan, pengelolaan TBM $\mathrm{W}$ tidak didukung dengan administrasi yang baik sehingga tidak terdokumentasi kegiatan yang dilakukan, daftar bahan bacaan, pengunjung dan bahan bacaan yang dipinjam warga.

\section{TBM Al-Mukhlisin}

TBM AM berada di lingkungan pemukiman penduduk yang diharapkan dapat menarik minat membaca masyarakat di sekitarnya. Akan tetapi ketika dilakukan observasi tidak terlihat ada pengunjung di TBM AM, pada hal observasi dilakukan pada jam operasi TBM AM. Jumlah koleksi yang tidak lebih dari 30 eksemplar terkesan terlalu minim untuk suatu TBM yang telah menerima bantuan dana dari Kemdiknas untuk mengembangn TBM itu. Sungguhpun dalam persyaratan penerima dana bantuan TBM, harus ada struktur organisasi dan beberpa pengurus, TBM AM kelihatannya hanya dikelola oleh ketuanya saja. Dalam pengelolaannya tidak terlihat dokumen penggunaan dana bantuan Kemdiknas, juga tidak terlihat daftar koleksi bahan bacaan, daftar pengunjung, daftar buku yang dipinjam, dan dokumen kegiatan TBM AM.

4. TBM Lembaga Pengembangan Pelestarian Dongeng

Di alamat yang disebutkan dalam dokumen ditemukan rumah yang di bagian luarnya terlihat spanduk tentang kegiatan TBM LPPD, akan tetapi tidak terlihat adanya kegiatan yang sedang berlangsung. Rumah tersebut merupakan tempat tinggal keluarga. Sumber informasi, perempuan yang mengaku sebagai pembantu rumah tangga di rumah itu tidak mengetahui kegiatan TBM LPPD. Tidak ditemukan sumber informasi lain karena pengelola TBM LPPD sedang tidak berada di tempat.

Tidak beroperasinya TBM LPPD, karena Ketuanya tidak berada di tempat seharusnya tidak terjadi apabila Bendahara atau Sekretaris TBM LPPD berada di tempat. Pembantu rumah tangga tidak mengetahui kegiatan TBM LPPD sungguh pun dia bekerja di rumah yang juga menjadi alamat TBM LPPD. Gejala-gejala ini 
memberikan pertanda TBM LPPD tidak berkembang serta tidak aktif sebagaimana diharapkan.

\section{TBM Paja Mandiri}

TBM PM merupakan salah satu unit dari PKBM

PM dan berlokasi di tempat yang ramai dan di dekat pemberhentian bus antarkota. Secara memberikan pelayanan peminjaman bahan bacaan, akan tetapi selain peserta didik PAUD dan peserta kursus yang diselenggarakan PKBM, TBM PM kurang dikunjungi oleh masyarakat sekitar.

Suasana dalam bangunan tempat PKBM PM menunjukkan kegiatan PKBM lebih mengarah pada penyelenggaraan PAUD dan kursus-kursus. Oleh karena tidak berhasil bertemu dengan pengelola TBM PM, tidak dapat diperoleh informasi tentang penggunaan dana bantuan Kemdiknas untuk TBM ini. Informasi yang ada menunjukkan bahwa masyarakat sekitar TBM PM ini kurang memanfaatkanTBM PM.

\section{TBM Al- Ikhlas}

TBM Al berdiri atas inisiatif warga masyarakat dengan idealisme untuk meningkatkan pendidikan warga melalui penyediaan bahan bacaan. Lokasi yang strategis serta berdekatan dengan kegiatan masyarakat membuaut TBM Al dimanfaatkan oleh warga sekitarnya. Kreatifitas pengelola dalam mengembangkan berbagai kegiatan yang berkaitan dengan membaca semakin menarik minat masyarakat untuk mengunjunginya.

Bantuan dana dari Kemdiknas dipergunakan untuk pengadaan koleksi dan kegiatan TBM AI. Dari awal dan dalam perkembangannya TBM Al tidak menggantungkan kegiatannya pada dana bantuan Pemerintah tetapi secara aktif menggali dan memanfaatkan sumber daya yang ada dimasyarakat. Dengan sikap yang demikian TBM Al dapat bertahan dan berkembang. Pengelolaan dan perkembangan TBM AI kurang didukung dengan administrasi yang tertib dan lengkap sehinga tidak diketahui secara tepat jumlah judul dan eksemplar bahan bacaan yang ada, data pengunjung serta bahan bacaan yang diminati pengunjung. Sumber informasi hanya dapat memberikan data perkiraan dan bersifat umum.

\section{TBM Al-Hidayah}

TBM Al-Hidayah merupakan unit/bagian dari TBM Al-Hidayah. Akan tetapi pengelolaan TBM AlHidayah dipercayakan sepenuhnya kepada Ketuanya dan nampaknya pengurus lain kurang berperan dalam pengelolaan TBM itu. Ketika Ketua TBM tidak ada di tempat, pengurus lain tidak melakukan kegiatan di TBM dan kunci sekretariat TBM juga dipegang oleh Ketua TBM. Kegiatan TBM ini juga tidak jelas dan tdak diketahui dengan baik oleh Ketua PKBM Al-Hidayah sebagai induk organisasi TBM Al-Hidayah. Sekiranya TBM Al Hidyah beroperasi secara teratur, seharusnya terdapat kegiatan-kegiatan di TBM tersebut. Informasi yang diperoleh menunjukkan bahwa TBM Al-Hidayah tidak aktif ketika dilakukan kunjungan ke lokasi.

\section{Analisis Data}

Analisis berikut ini dilihat dari enam aspek yaitu (1) kesesuaian alamat, (2) keberadaan fisik TBM, (3) sumber informasi, (4) koleksi bahan bacaan TBM, (5) kegiatan TBM, dan (6) administrasi pengelolaan TBM. 1. Alamat

Dari 7 TBM yang diteliti, ternyata ada 1 TBM $(14,3 \%)$ yang tidak berlokasi di alamat yang sesuai dengan data alamat dalam dokumen yang diperoleh dari Direktorat Pendidikan Masyarakat. Alamat TBM tersebut (Al-Hidayah) tidak diketahui secara jelas walaupun dapat ditemukan alamat PKBM yang mewadahi TBM Al-Hidayah. Kemungkinan pada waktu mengajukan proposal, ketua TBM Al-HIdayah menggunakan alamat PKBM Al-Hidayah. Perbedaan alamat ini seharusnya sudah diketemukan waktu dilakukan verifikasi oleh tim dari Direktorat Pendidikan Masyarakat. Sedangkan 6 TBM lainnya $(85,7 \%)$ memiliki alamat yang sama dengan di dokumen.

\section{Keberadaan fisik TBM}

Dari 7 TBM yang diobservasi, 1 TBM (14,3\%) tidak ditemukan bangunan fisik TBM (TBM Al-Hidayah). Sedangkan 6 TBM lainnya $(85,7 \%)$ memiliki ruang atau bangunan yang jelas.

3. Sumber informasi

Dari 7 TBM yang diteliti terdapat 1 TBM (14,3\%) yang tidak ditemukan sumber informasinya (TBM LPPD) terdapat orang yang bekerja sebagai pembantu rumah tangga. Orang tersebut tidak bersedia memberikan informasi sama sekali tentang kegiatan TBM LPPD. Pembantu rumah tangga ini sangat tertutup dalam memberikan informasi dan menyarankan agar menanyakannya langsung kepada penelolanya yang sedang melaksanakan ibadah umroh. Kebetulan pula pada waktu dilakukan observasi ke TBM LPPD tidak dapat ditemukan anggota masyarakat setempat yang dapat dijadikan sumber infarmasi.

TBM diharapkan terbuka untuk umum dan masyarakat dapat mengetahui kegiatanya. Dengan demikian, pembantu rumah tangga itu seharusnya mengetahui kegiatan TBM LPPD dan dapat memberikan informasi secara umum. Tidak bersedianya pembantu rumah tangga yang tinggal di lokasi TBM LPPD menimbulkan keragu-raguan, apakah TBM ini masih melakukan kegiatan atau tidak.

Sementara itu, di 2 TBM lainnya $(28,6 \%)$ terdapat sumber informasi yang diharapkan seharusnya 
dapat memberikan penjelasan tentang TBM yang bersangkutan, karena yang bersangkutan adalah sekretaris TBM atau salah seorang pengurus PKBM yang mewadahi TBM yang bersangkutan. Akan tetapi narasumber di 2 TBM tersebut (TBM Paja Mandiri dan TBM Al-Hidayah) tidak dapat memberikan informasi yang lengkap seperti diharapkan. Kurangnya informasi yang diperoleh dari sumber yang demikian menunjukkan gejala bahwa manajemen TBM itu tidak terbuka, kurang dikenal atau kegiatannya tidak begitu jelas lagi.

Di empat TBM $(57,1 \%)$ ditemukan ketua TBM yang sekaligus dijadikan sumber informasi. Dengan demikian informasi yang diberikan diharapkan dapat dipercayai dan akurat. Akan tetapi dalam hubungannya dengan penggunaan dana bantuan dari Kemdiknas, sumber informasi tidak dapat memberikan informasi dan data yang rinci. Sebagai contoh disebutkan, dana itu dipergunakan untuk membeli buku, insentif untuk pengelola, dan kegiatan operasional TBM. Gejala ini menimbulkan pertanyaan sejauh mana TBM konsisten menggunakan dana bantuan sesuai dengan propsal yang mereka susun dan disetujui Direktorat pendidikan Masyarakat.

\section{Koleksi bahan bacaan TBM}

Koleksi bacaan seharusnya menjadi andalan dan menjadi daya tarik setiap TBM. Oleh karena itu dana bantuan Kemdiknas diharapkan dipergunakan terutama untuk meningkatkan jumlah dan jenis bahan bacaan TBM. Di samping itu bahan bacaan yang disediakan diharapkan sesuai dengan kebutuhan masyarakat setempat dilihat latar belakang pendidikan dan pekerjaannya.

Dari 7 TBM, ditemukan 2 TBM (28,6\%) memiliki koleksi yang cukup berkembang yaitu TBM Paja Mandiri dan TBM Al-Ikhlas. Di 3 TBM (42,8\%) ditemukan jumlah koleksinya sangat minim atau kurang dari 50 judul dan tidak terlihat penambahan koleksi setelah menerima dana bantuan dari Kemdiknas. Sedangkan di 2 TBM (28.6\%) tidak diketahui koleksi bahan bacaan secara jelas, karena dapat diamati atau beralih fungsi.

Hasil observasi dalam penelitian ini menunjukkan bahwa kokesi bahan bacaan di sebagaian besar TBM tidak berkembang sesuai dengan diharapkan walaupun telah menerima dana bantuan. Oleh karena koleksi bahan bacaan menjadi daya tarik, sulit dapat diharapkan TBM ini dikunjungi oleh banyak warga masyarakat sekitarnya bahkan oleh peserta didik di sekolah yang berada di dekat TBM.

Data di TBM tidak menunjukkan adanya pemantauan dari instansi atau lembaga tertentu termasuk dari Direktorat Pendidikan Masyarakat tentang penggunaan dana bantuan Kemendiknas. Tidak adanya monitoring dan pengawasan ini dapat mengakibatkan masing-masing TBM penerima dana tidak menggunakan dana yang mereka peroleh sesuai dengan propsal. Kecurigaan ini semakin menguat karena di kebanyakan TBM tidak dapat ditemukan arsip proposal permintaan dana bantuan sungguhpun untuk bantuan yang diberikan tahun 2010.

\section{Kegiatan TBM}

Pada awalnya TBM lahir atas dasar inisiatif anggota masyarakat, berada di tengah-tengah masyarakat dan dipergunakan oleh warga masyarakat sekitar. Bahan bacaan yang disediakan TBM diharapkan dapat memotivasi pengunjungnya membaca untuk mendapatkan hiburan atau belajar sesuatu untuk menambah pengetahuan dan keterampilannya. Mengingat keberadaan TBM yang strategis sebagai wadah untuk mencerdaskan bangsa, mulai tahun 1992 Pemerintah mendorong pendirian dan pertumbuhan TBM tidak hanya sebagai tempat memperoleh bahan bacaan tetapi juga sebagai pusat belajar masyarakat.

Dengan peran serta Pemerintah dalam mengembangkan TBM, masing-masing TBM diharapkan juga mendorong dan membudayakan minat dan kegemaran membaca, menyelenggarakan diskusi-diskusi berkaitan dengan isi buku dikaitkan dengan pengembangan dan peningkatan kualitas pekerjaan warga masyarakat, melakukan kursus-kursus praktis berbasis lingkungan, sampai pada penyelenggaraan paket $A$, B, dan C.

Data di 7 TBM yang diobservasi menunjukkan bahwa hanya 1 TBM $(14,3 \%)$ yang menyelenggarakan kegiatan untuk meningkatkan minat dan kegemaran membaca warga sekitarnya. TBM yang dimaksud ialah TBM Al-lkhlas. Sedangkan yang lainnya $(85,7 \%)$ tidak menunjukkan perkembangan kegiatan. Sungguhpun ada beberapa TBM yang memberikan informasi bahwa dana bantuan Kemdiknas juga dipakai untuk melakukan lomba membaca dan menulis, tetapi kegiatan itu tidak berkelanjutan. TBM cenderung kembali menyediakan bahan bacaan seadanya dan juga tidak mengembangkan koleksi bahan bacaan sesuai dengan karakteristik masyarakat sekitarnya. Jumlah, jenis, dan kualitas kegiatan di kebanyakan TBM tidak bertambah seperti yang diharapkan.

Tidak berkembangnya kegiatan TBM tidak terlepas dari pengelola TBM yang berdasarkan hasil observasi pengelolaan TBM dilakukan dan sangat tergantung pada ketua TBM. Sedangkan peranan sekretaris, bendahara, atau petugas lainnya yang terceantum dalam proposal, tidak jelas. Sedangkan ketua TBM itu sendiri memiliki pekerjaan utama lain yang menyita banyak waktu. Keadaan yang demikian 
dapat menjadi salah satu penyebab alasan tidak berkembangnya kegiatan TBM.

\section{Administrasi pengelolaan TBM}

Administrasi pengelolaan TBM yang diobservasi mencakup dokumen, termasuk dokumen penggunaan dan bantuan dari Kemdiknas, dokumentasi kegiatan TBM, daftar koleksi bahan bacaan, daftar pengunjung, dan daftar peminjam buku. Dari semua TBM yang diobservasi, tidak ditemukan dokumen tertulis tentang penggunaan dana bantuan Kemdiknas sungguh pun dana itu diperoleh pada tahun 2010, yang seharusnya masih tersedia secara lengkap. Oleh karena itu, informasi yang diperoleh secara lisan dari sumber informasi tentang penggunaan dana itu tidak dapat didukung dengan bukti-bukti yang tertulis atau secara fisik. Sebagai contoh, kebenaran mengenai pembelian bahan bacaan dengan menggunakan dana bantuan, tidak dapat diyakini sepenuhnya. Apalagi dari 7 TBM yang diamati hanya terlihat 1 TBM yang memilki koleksi jumlah koleksi bahan bacaan yang memadai. Dan tidak ada satu TBM pun yang memiliki daftar koleksi bahan bacaan.

Demikian juga mengenai informasi tentang kegiatan TBM yang bersumber dari dana bantuan Kemdiknas sulit dapat diyakini kebenarannya karena tidak diukung dengan bukti dokumentasi berupa foto atau laporan. Kalaupun terdapat kegiatan TBM dengan dukungan dana bantuan, ternyata kegiatan itu tidak berkelanjutan dalam tahun 2011. Dengan perkataan lain, kegiatan TBM tidak berkembang dengan sendirinya kalau dana bantuan sudah habis.

Jumlah pengunjung TBM yang diobservasi tidak lebih rata-rata dari lima orang pengunjung setiap hari. Bahkan ada yang hanya rata-rata lima orang dalam satu minggu. Kepastian tentang jumlah pengunjung tidak dapat diketahui karena tidak terdapat daftar pengunjung dan daftar buku yang dipinjam. Kalaupun terdapat pengunjung rata-rata lima orang perhari, jumlah pengunjung tersebut sangat kurang dilihat dari jam operasi TBM yang paling sedikit 3 jam setiap kali dibuka. Dengan sedikitnya pengunjung tersebut, diharapkan TBM melakukan sosialisasi atau peningkatan minat dan gemar membaca masyarakat sekitar, khususnya TBM yang berdekatan dengan KB, PAUD, SD, atau Madrasah. Akan tetapi, sosialisasi TBM seperti itu, pada umumnya tidak dilakukan.

Dari hasil observasi serta intepretasi seperti yang telah dikemukakan, terlihat TBM yang memperoleh dana bantuan dari Kemdiknas pada tahun 2010 tidak seperti yang diharapkan. Masing-masing TBM menerima dana bantuan satu sampai dua tahun sebelum observasi dalam penelitian dilakukan. Akan tetapi hasil penggunaan dana itu tidak terlihat secara nyata.

Berdasarkan ketentuan, dana bantuan yang diberikan kepada TBM harus didahului dengan proposal yang isinya antara lain mengenai keadaan fisik, struktur organisasi, pengelola, koleksi bahan bacaan yang sudah dimiliki, serta rencana penggunaan dana yang diajukan oleh masing-masing TBM. Dana bantuan akan diberikan setelah melalui penilaian oleh tim khusus di Direktorat Pendidikan Masyarakat serta kebenaran isi proposal diverifikasi di tempat TBM oleh tim yang dibentuk TBM Dengan mekanisme dan prosedur yang demikian diharapkan TBM yang menerima dana bantuan betul-betul TBM yang secara fisik sudah ada dan melakukan kegiatan, serta sungguh-sungguh berniat untuk mengembangkan pengetahuan dan keterampilan masyarakat melalui layanan dan kegiatan TBM.

Mekanisme dan prosedur pemberian dana bantuan yang dibuat dan dilaksanakan oleh Direktorat Pendidikan Masyarakat ternyata tidak sepenuhnya menjamin pertumbuhan dan perkembanngan TBM menjadi pelaksana dan penggerak pengembangan minat dan kegemaran membaca masyarakat, apa lagi menjadikan TBM sebagai sumber belajar masyarakat. Keadaan ini dapat terjadi karena sumber daya di TBM tidak difungsikan sebagaimana mestinya, pengetahuan tentang tugas dan fungsi TBM masih minim, kepekaan dan kreatifitas untuk mengembangkan kegiataan juga masih kurang, serta kemampuan menggali dan mengembangkan sumber-sumber dana dangat lemah.

Dalam Acuan Pengajuan dan Pengelolaan Dana Program Taman Bacaan Masyarakat Penguatan Minat Baca tahun 2010 disebutkan bahwa Direktorat Pendidikan Masyarakat dan/atau DInas Pendidikan Propinsi dan/atau Dinas Pendidikan Kabupaten/Kota melakukan monitoring dan evaluasi atas penggunaan dana bantuan yang diterima TBM. Akan tetapi data di TBM yang diteliti tidak terdapat bukti-bukti tertulis bahwa monitoring dan evaluasi itu dilakukan. TBM penerima bantuan terkesan merasa tidak terikat pada rencana penggunaan dana yang mereka sebutkan dalam proposal pengajuan dana bantuan. Lemahnya pengawasan ini dapat mengakibatkan dana bantuan yang diberikan tidak dipergunakan untuk mencapai tujuan pemberian danan tersebut.

Dalam wawancara dengan ketua TBM, terungkap bahwa terdapat perbedaan antara satu sampai tiga tahun selang antara pengajuan proposal permintaan dana bantuan dengan realisasi pemberian bantuan. Berdasarkan ketentuan yang ada, tindak 
lanjut proposal (diterima atau ditolak permintaan dana bantuan) seharusnya sudah diberitahu kepada TBM peminta dana bantuan satau atau paling lama dua tahun sesduadah Direktorat Pendidikan Masyarakat menerima proposal. Keterlambatan pemberian dana ini mungkin bersifat kasus dan perlu penelusuran lebih lanjut.

Mekanisme dan prosedur dalam memberikan dana bantuan kepada TBM memberikan jaminan bahwa pemberian dana bantuan itu dilakukan secara terbuka, adil, jujur, dan objektif. Akan tetapi dalam wawancara dengan beberapa ketua TBM terungkap adanya kesan bahwa mereka berhasil memperoleh dana bantuan karena ada hubungan dan bantuan dari orang di Dinas Pendidikan atau Direktorat Pendidikan Masyarakat. Sejauh mana kebenaran informasi tersebut perlu ditelusuri lebih lanjut dan diluruskan sehingga terungkap kenyataan sesungguhnya bahwa penentuan TBM yang memperoleh dan bantuan dilakukan secara objektif.

Dalam Acuan Pengajuan dan Pengelolaan Dana Program Taman Bacaan Masyarakat Penguatan Keaksaraan (2010) disebutkan bahwa pemberian dana bantuan dimaksudkan untuk menyediakan, memperluas dan meratakan akses TBM sehingga menjangkau dan memberikan layanan peningkatan keberaksaraan dan memberdayakan masyarakat. Hasil observasi serta informasi dan data yang diperoleh di TBM penerima dana yang diobservasi dalam penelitian ini menunjukkn tujuan tersebut belum tercapai. Keadaan yang ada di hamper semua TBM yang diteliti juga tidak mengarah ke pencapaian tujuan itu.

\section{Keterbatasan Penelitian}

Dilihat dari pendekatannya, penelitian ini ter- masuk penelitian kualitatif yang dilakukan terbatas di 7 TBM di empat kabupaten di Propinsi Banten, yaitu (1) Kabupaten Lebak, (2) Kabupaten Tangerang, (3) Kabupaten Serang, dan (4) Kota Serang. Kabupaten yang dipilih tidak mewakili seluruh wilayah Propinsi Banten. Demikian juga TBM yang dipilih tidak mewakili TBM di kecamatan, kabupaten, dan propinsi yang bersangkutan.

Analisis dan kesimpulan yang dibuat merupakan kesimpulan sementara dan untuk dapat digeneralisasi masih diperlukan penelitian lebih lanjut ke TBM lainnya sehingga bergulir seperti bola salju dan menjadi lebih lengkap serta sampai pada titik jenuh yang memberikan indikasi temuan tidak baru berbeda lagi dengan teman sebelumnya.

Oleh karena keterbatasan waktu, peneliti tidak dapat membaur secara alamiah di masing-masing TBM untuk memperoleh dan menghayati informasi dan kegiatan TBM secara lebih mendalam. Sungguhpun demikian peneliti telah berupaya memperoleh indormasi dan data seakurat dan sebenar mungkin. Pengalaman dalam penelitian ini diharapkan dapat dijadikan acuan untuk melakukan penelitian lebih lanjut pada waktu yang akan datang.

Di Direktorat Pendidikan Masyarakat dan di sejumlah TBM tidak dapat ditemukan proposal permintaan dana bantuan dari TBM ke Direktorat Pendidikan Masyarkat, sehingga sulit dapat melakukan perbandingan secara cermat dan lengkap antara kesesuaian pelaksanaan proposal yang dibuat oleh masing-masing TBM. Keadaan yang demikian membuat data dan analisis serta kesimpulannya terkesan kurang rinci dan kurang kritis.

\section{PENUTUP}

\section{Kesimpulan}

Tujuan utama penelitian ini ialah memberikan gambaran perkembangan TBM yang menerima dana bantuan dari Kementerian Pendidikan melalui Derektorat Pendidikan Masyarakat dalam tahun 2010. Semua TBM yang diobservasi menerima dana bantuan dalam tahun 2010 . Tahun 2010 penerimaan dana bantuan itu dipilih dengan pertimbangan hasil penggunaan dana bantuan itu masih dapat terlihat dengan lengkap dan jelas. Semua TBM yang diobservasi tersebar di 4 kabupaten/kota di Propinsi Banten.

Dari analisis data dan informasi yang diperoleh melalui observasi/pengamatan, wawancara, serta studi dokumen dapat disimpulkan sebagai berikut.

1. Pada umumnya, tidak terlihat pertambahan koleksi yang berarti dan perkembangan kegiatan TBM un- tuk meningkatkan minat dan kegemaran membaca di kebanyakan TBM yang menerima dana bantuan dalam tahun 2010. Bahkan terdapat TBM yang tidak jelas keberadaannya.

2. Kebanyakan TBM yang masih aktif melakukan kegiatan terbatas menyediakan bahan bacaan yang jumlahnya juga tidak memadai dengan jenis bahan bacaan yang kurang bervariasi dan berorientasi kepada kebutuhan warga sekitar.

3. Jumlah pengunjung sangat sedikit dibandingkan dengan waktu yang disediakan oleh TBM. Keadaan ini terkait dengan kurangnya jumlah dan jenis bahan bacaan yang tersedia serta kurangnya kegiatan TBM meningkatkan minat dan kegemaran membaca warga sekitar.

4. PKBM yang mewadahi TBM cenderung mengem- 
bangkan kegiatan lain seperti menyelenggarakan Kelompok Bermain, PAUD Atau TK dan kurang mengembangkan TBM. PKBM mengharapkan anak-anak KB, PAUD, TK atau sekolah yang ada di sekitar TBM memanfaatkan TBM. Akan tetapi, harapan itu tidak disertai dengan usah proaktif untuk menarik perhatian anak-anak dan warga sekitarnya.

5. Pengelolaan TBM tidak didukung dengan administrasi yang lengkap dan tertib sehingga sulit dapat diketahui jumlah, jenis, serta koleksi bahan bacaan di TBM, jumlah pengunjung, bahan bacaan yang dipinjam pengunjung, serta kegiatan-kegiatan yang dilakukan TBM.

6. Tidak ditemukannya dokumen atau bukti-bukti pendukung mengakibatkan tidak dapat diketahui secara tepat penggunaan dana bantuan yang diterima TBM dari Direktorat Pendidikan Masyarakat dalam tahun 2010. Terdapat gejala bahwa TBM penerima dana bantuan tidak mengacu secara ketat pada proposal yang mereka ajukan untuk memperoleh dan dari Direktorat Pendidikan Masyarakat.

7. Hasil penelitian menunjukkan TBM yang menerima dana bantuan sulit dapat diharapkan menjadi wadah yang dapat memasyarakat gemar membaca dan belajar. Keadaan yang ada juga tidak memberikan harapan TBM penerima dana bantuan dapat mencapai tujuan pemberian dana TBM Penguatan Keaksaraan.

8. Kurang berkembangnya TBM penerima dana bantuan nampaknya disebabkan oleh dua faktor utama yaitu manajemen/pengelolaan yang lemah karena dan tidak ada atau kurangnya monitoring dan pengawasan penggunaan dana bantuan tersebut dari Direktorat Pendidikan Masyarakat.

Implikasi

Data, informasi, analisis, dan kesimpulan penelitian ini menunjukkan bahwa perkembangan TBM yang memperoleh dana bantuan sosial dari Pemerintah melalui Kemendiknas dan secara operasional disalurkan oleh Direktorat Pendidikan Masyarakat, Direktorat Jenderal Pendidikan Nonformal dan Informal, dalam tahun 2010, belum dapat mengembangkan TBM menjadi penguat keaksaraan di tengah-tengah masyarakat. Dengan dana bantuan sosial itu diharapkan TBM dapat meningkatkan kemampuan keberaksaraan dengan sasaran anak usia dini, melek aksara parsial, peserta didik pendidikan dasar, anak yatim piatu di panti asuhan, dan masyarakat pada umumnya. Selanjutnya, pemberian bantuan dana sosial dimaksudkan untuk menyediakan, memperluas, dan meratakan akses TBM sehingga menjangkau dan memberikan layanan peningkatan keberaksaraan dan memberdayakan masyarakat.

Kurang berhasilnya pencapaian tujuan pemberian bantuan dana sosial karena kebanyakan TBM yang diobservasi dalam penelitian ini merupakan salah satu unit dari PKBM. Di samping TBM, PKBM juga mengelola kegiatan lain seperti Kelompok Bermain dan Taman Kanak-Kanak atau kursus keterampilan. Kelihatannya PKBM memberikan perhatian lebih banyak kepada kegiatan pendidikan usia dini atau kursus-kursus lain dan TBM kurang dikembangakan dan dimanfaatkan. Di samping itu, kesibukan ketua TBM dan kurang berfungsinya pengurus lain di TBM membuat kegiatan TBM tidak berkembang dan pengelolaan administrasi TBM tidak tertib.

Sungguhpun diperoleh informasi TBM penerima dana bantuan sosial menggunakan dana itu untuk penambahan koleksi dan melakukan kegiatan meningkatkan minat baca, tetapi informasi tersebut tidak didukung dengan fisik dan dokumen yang autentik. Kalaupun informasi itu benar, ternyata penambahan koleksi dan pengembangan kegiatan tidak berkelanjutan yang berarti dana bantuan itu tidak berfungsi sebagai pengungkit atau pemicu berkembangnya TBM.

Namun, perlu juga diketahui masih terdapat dua TBM yang memiliki koleksi yang cukup baik dan melakukan kegiatan meningkatkan minat baca masyarakat. Kedua TBM tersebut dikelola oleh orang yang memilki motivasi yang kuat untuk mewujudkan cita-citanya mencerdaskan masyarakat setempat.

Berangkat dari kenyataan yang ditemukan di masing-masing TBM nampaknya kebijakan pemberian dana bantuan sosial kepada TBM perlu disertai dengan mekanisme dan prosedur yang menjamin tercapainya tujuan pemberian bantuan dana sosial itu. Mekanisme tersebut mulai dari pengajuan proposal, proses seleksi, pelaksanaan proposal, pemantauan, dan evaluasi dana bantuan sosial. Peranan Dinas di tingkat kabupaten/kota dan propinsi hendaknya lebih ditingkatkan khususnya dalam pemantauan dan penggunaan dana bantuan sosial kepada TBM.

Kemampuan pengelola TBM nampaknya juga perlu ditingkatkan melalui pelatihan pengelolaan TBM yang dapat dilakukan di tingkat kabupaten/kota dan propinsi sehingga motivasi dan kreativitas mereka mengembangkan TBM, semakin meningkat. Apabila tidak dilakukan perbaikan dikhawatirkan pemberian dana bantuan sosial itu tidak akan mencapai sasaran dan tujuannya dan negara dirugikan.

Penelitian ini dilakukan hanya di 7 TBM dengan hasil yang belum sesuai dengan harapan dan tidak dapat diberlakukan untuk semua TBM. Mungkin saja 
terjadi, fenomena yang ditemukan dan dideskripsikan tidak berlaku di TBM lain. Oleh karena itu untuk memperoleh hasil yang lebih lengkap dan dapat digeneralisasi, penelitian ini perlu dikembangkan ke TBM-TBM lain.

\section{Saran}

Temuan dalam penelitian menunjukkan pada umumnya perkembangan TBM penerima dana bantuan dari Kemdiknas tidak sperti yang diharapkan. Mengacu pada kondisi yang ada serta mengarah pada kondisi yang diharapakan, penelitian ini memberikan saran sebagai berikut.

1. Direktorat Pendidikan Masyarakat meningkatkan penilaian dan seleksi TBM yang mengajukan permintaan dana bantuan secara konsisten, objektif, dan terbuka. Verifikasi kebenaran isi proposal TBM hendaknya dikembangkan di lapangan dengan mencermati lebih teliti dan mendalam motif TBM mengajukan permintaan dana bantuan, TBM yang lahir secara mandiri dan memiliki idealisme yang kuat hendaknya diprioritaskan dalam memberikan dana bantuan apa bila syarat-syarat lainnya telah terpenuihi.

2. Direktorat Pendidikan Masyarakat dan Dinas Pendidikan ditingkat Propinsi atau Kabupaten/Kota hendaknya meningkatkan jumlah dan kualitas pelatihan di bidang teknis dan administratif untuk pengelola TBM.

3. Direktorat Pendidikan Masyarakat dan Dinas Pendidikan di Kabupaten hendaknya melakukan monitoring dan pengawasan secara periodik atas penggnaan dan bantuan dari Kemdiknas dengan menggunakan proposal pengajuan dana bantuan yang sebelumnya dibuat dan disampaikan ke Direktorat Pendidikan Masyarakat oleh TBM penerima dana.

4. Dengan mengatasi keterbatasan penelitian ini, hendaknya dilakukan penelitian yang sejenis mencakup lebih banyak TBM di wilayah yang berbeda untuk keperluan generalisasi.

\section{DAFTAR PUSTAKA}

"Minat Baca : Akses Buku Bagi Anak Miskin Terbatas". Kompas, 26 Mei 2006 hal : 12

"Publik dan Buku : Jajak Pendapat 'Kompas" - Perpustakaan Miskin Peminat". Kompas, 19 Maret 2005 hal : 52

ACCU, (1988) Report. Paris: Unesco

Creswell, J.W. (1998). Qualitative inquiry and research design. London: Sage Publications.

Denzin, N.K. \& Lincoln, Y.S. (1994). Handbook of qualitative research. Thousand Oaks, CA: Sage Publications.

Departemen Pendidikan Nasional. (2004). Rencana strategis Departemen Pendidikan Nasional tahun 2005-2009 (RPJMN 2005-2009). Jakarta: Departemen Pendidikan Nasional.

Direktorat Pendidikan Masyarakat. (2006a). Panduan penyelenggaraan Taman Bacaan Masyarakat. Jakarta: Departemen Pendidikan Nasional.

Direktorat Pendidikan Masyarakat. (2006a). Panduan penyelenggaraan Taman Bacaan Masyarakat. Jakarta: Departemen Pendidikan Nasional.

Direktorat Pendidikan Masyarakat. (2006b). Panduan pengelolaan Taman Bacaan Masyarakat. Jakarta: Departemen Pendidikan Nasional.

Direktorat Pendidikan Masyarakat. (2007). Direktori TBM tahun 2007. Jakarta: Departemen Pendidikan Nasional.

Direktorat Pendidikan Masyarakat. (2008). Pedoman penyaluran bantuan sosial program pengem- bangan budaya baca dan pembinaan perpustakaan. Jakarta: Departemen Pendidikan Nasional.

Direktorat Pendidikan Masyarakat. (2010). Acuan dan pengelolaan : Program Taman Bacaan Bacaan penguatan keaksaraan. Jakarta: Kementerian Pendidikan Nasional

Djokosuyatno , L. (2005). “ Kendala Dalam Komunikasi Inovasi Kepustakawanan : Suatu Pendekatan Berwawasan Kebudayaan" Republika, 4Juli 2003

Ella, Y. (ed). (2010). Taman bacaan masyarakat kreatif. Jakarta: Kementerian Pendidikan Nasional.

Haklev, S. (2008). Mencerdaskan bangsa - An inquiry into the phenomenon of Taman Bacaan in Indonesia. B.A. Thesis. International Development Studies. University of Toronto at Scarborough.

Maddox, H. (1964). How to study. New York: Crest Books, Fawcett World Library.

Pengelola Perpustakaan Sekolah Perlu Paham Kebutuhan Siswa". Kompas, 12 Mei 2005 hal: 9

Staigner, R. C. (ed.). 1973. The teaching of reading. Paris: Ginn and Company, A Xerox Education Company.

Supriyoko, K. (2005). Minat baca dan kualitas bangsa. Diakses dari http://smp.alkausar.org/detail-artikel. php?id=118 pada tanggal 11 Februari 2011

Undang-Undang Dasar Republik Indonesia Tahun 1945. 
Undang-Undang Republik Indonesia No 20 Tahun 2003 Tentang Sistem Pendidikan Nasional.

Undang-Undang Republik Indonesia No. 43 Tahun 2007 Tentang Perpustakaan.

Unesco. (2004). Education for all: Global monitoring report 2005. Paris: UNESCO.

Wendyartaka, A. (2005). Minat baca masyarakat terhadang daya beli". Kompas, 19 Februari 2005 www.bappenas.go.id/get-file-server/node/6180/hlm.22 